\title{
Histological aspects of the mucosa of the spermaceti chamber of a dwarf sperm whale
}

\section{Aspectos histológicos da mucosa da câmera do espermacete de cachalote-anão}

\author{
Samira COSTA-SILVA ${ }^{1}$; Carlos SACRISTÁN ${ }^{1}$; Kátia Regina GROCH ${ }^{1}$; Angélica María SÁNCHEZ- \\ SARMIENTO $^{1}$; Laura REISFELD ${ }^{1}$; Gustavo DUTRA ${ }^{2}$; Cristiane LASSÁLVIA ${ }^{2}$; José Luiz CATÃO- \\ DIAS $^{1}$
}

${ }^{1}$ Universidade de São Paulo, Faculdade de Medicina Veterinária e Zootecnia, Laboratório de Patologia Comparada, São Paulo - SP, Brazil

${ }^{2}$ Aquário de Santos, Santos - SP, Brazil

\begin{abstract}
The sound producing apparatus of the dwarf sperm whale (Kogia sima) presents a complex anatomic structure composed of melon, spermaceti, phonic lips, vocal cap, case, papillae, spermaceti chamber and other airspaces, as well as facial muscles involved in sound production. The spermaceti chamber rests on the caudal portion of the premaxilla, with part of its mucosa covered with spherical/oval-shaped structures (approximately 1 to $2 \mathrm{~mm}$ in diameter), compatible with vesicles (previously referred to as "papillae"). Macroscopical examination revealed whitish, firm, widely and irregularly distributed vesicular mucosa on the premaxillary portion of the spermaceti chamber of a $K$. sima specimen stranded on the coast of Santos (southeastern Brazilian coast). Upon microscopic examination, walls of connective tissue with abundant type I collagen forming vesicles with an internal space or cavity filled with a small amount of eosinophilic substance compatible with mucoproteic fluid were observed. The base of such vesicles presented glands within the connective tissue, probably responsible for fluid production. This study describes the histology of the mucosa of the spermaceti chamber of a $K$. sima specimen and characterizes the glands associated with fluid production.
\end{abstract}

Keywords: Cetacean. Histology. Sound production. Spermaceti. Kogiidae.

\section{Resumo}

O sistema de produção sonora do cachalote-anão (Kogia sima) apresenta uma complexa estrutura anatômica composta por melão, espermacete, lábios fônicos, "vocal cap", "case", papilas, câmara do espermacete e outros espaços aéreos, além de músculos faciais envolvidos na produção sonora. A câmara do espermacete localiza-se na porção caudal da pré-maxila, apresentando parte de sua mucosa recoberta por estruturas esférico-ovaladas de aproximadamente 1 a $2 \mathrm{~mm}$ de diâmetro, compatíveis com vesículas (previamente denominadas "papilas"). Ao exame macroscópico de um espécime de $K$. sima encalhado no litoral de Santos (sudeste da costa brasileira), foi identificada mucosa esbranquiçada e firme ao corte, ampla e irregularmente distribuída na porção pré-maxilar da câmara do espermacete. Ao exame microscópico foram observadas vesículas compostas por abundante tecido conectivo de colágeno tipo I, dando origem a um espaço interno ou cavidade, contendo pequena quantidade de substância eosinófila, compatível com fluido mucoprotêico. Estruturas glandulares foram observadas em tecido conjuntivo na base das vesículas, provavelmente responsáveis pela produção do fluido observado no interior das mesmas. Esse estudo caracteriza histologicamente a mucosa da câmara do espermacete de um espécime de $K$. sima e as glândulas relacionadas a sua produção secretória.

Palavras-chave: Cetáceo. Histologia. Produção sonora. Espermacete. Kogiidae. 
Correspondence to:

Samira Costa-Silva

Universidade de São Paulo, Faculdade de Medicina

Veterinária e Zootecnia, Laboratório de Patologia Comparada

Av. Professor Orlando Marques de Paiva, 87

CEP: 05508-270, São Paulo, SP, Brazil

e-mail: costasilva.samira@gmail.com

Received: 16/01/2016

Approved: 30/08/2016

The dwarf sperm whale (Kogia sima, Owen, 1866) belongs to the order Cetartiodactyla, suborder Odontoceti, family Kogiidae. The Kogia genus is composed of two species, the pygmy sperm whale (Kogia breviceps) and the dwarf sperm whale (K. sima) (REEVES et al., 2002), and both are classified as "data deficient species" by the International Union for Conservation of Nature (IUCN), due to the insufficient data available to determinate their conservation status (TAYLOR et al., 2012a, b). Sperm whale (Physeter macrocephalus) belongs to a separate family, Physeteridae (REEVES et al., 2002). Both families, Kogiidae and Physeteridae, have some characteristics in common, such as feeding behavior (cephalopods are their preferred item), deep diving abilities (JONES, 1981; SCOTT et al., 2001; WATWOOD et al., 2006; SPITZ et al., 2011) and presence of spermaceti (SCHENKKAN; PURVES, 1973).

Members of the family Kogiidae produce a series of clicks that correspond to echolocation signals, used for navigation and communication (CALDWELL et al., 1966; CALDWELL; CALDWELL, 1991; CLARKE, 2003). Their skull is greatly asymmetric, containing two nasal passages: a larger one on the left portion of the skull, used for breathing, and a smaller one on the right, responsible for sound production (WOOD, 1964; THORNTON et al., 2015). Clicks are produced and transmitted by a complex anatomic structure formed by the melon, phonic lips ("museau de singe" or "monkey lips"), vocal cap (or cushion), spermaceti, case, papillae, various air sacs, including the spermaceti chamber (also called nasofrontal air sac), and some facial muscles, mainly located in the left nasal passage (CLARKE, 2003; THORNTON et al., 2015). The vocal cap and the phonic lips rest on the vocal chamber, an airspace located on the caudal portion of the right premaxilla (THORNTON et al., 2015). Another airspace, the spermaceti chamber, which includes the spermaceti organ and its surrounding case, presents its caudal portion lined with spherical/oval-shaped structures of approximately $1-2 \mathrm{~mm}$ in diameter filled with a brownish-beige fluid (CLARKE, 2003; THORNTON et al., 2015). This study describes the histology of the mucosa of the spermaceti chamber and associated glands of a $K$. sima specimen.

A juvenile male $K$. sima stranded alive on the coast of Santos city $\left(23.99^{\circ} \mathrm{S}, 46.31^{\circ} \mathrm{W}\right.$ ) (State of São Paulo, southeastern Brazil) in May 2014, was rescued by the staff of the Aquário de Santos, but died within 24 hours. Necropsy was performed immediately and included examination and collection of the spermaceti chamber. Collected tissues were placed in 10\% neutral buffered formalin ( $\mathrm{pH} 7.4$ ), embedded in paraffin wax, sectioned at $5 \mu \mathrm{m}$ and stained with hematoxylin and eosin (HE), Masson's trichrome, alcian blue, periodic acid-Schiff (PAS) and alcian blue-PAS, according to routine histological techniques.

Upon macroscopic examination, the spermaceti chamber was attached to the right premaxilla, next to the spermaceti and melon. The mucosa of the spermaceti chamber contained multiple whitish, firm, widely and irregularly distributed vesicular structures (Figure 1). The vesicles were uniform in size, ranging from 1-2 $\mathrm{mm}$ in diameter, presenting an inner space or cavity, filled with fluid. Similar findings were previously described as papillae (CLARKE, 2003; THORNTON et al., 2015). Nevertheless, the structures described in this study were more consistent with vesicles, once fluid-filled cavities of less than $5 \mathrm{~mm}$ in diameter were observed.

Microscopically, vesicles lined by an outer layer of simple epithelium and an inner simple cuboid epithelium filled with small amounts of eosinophilic 


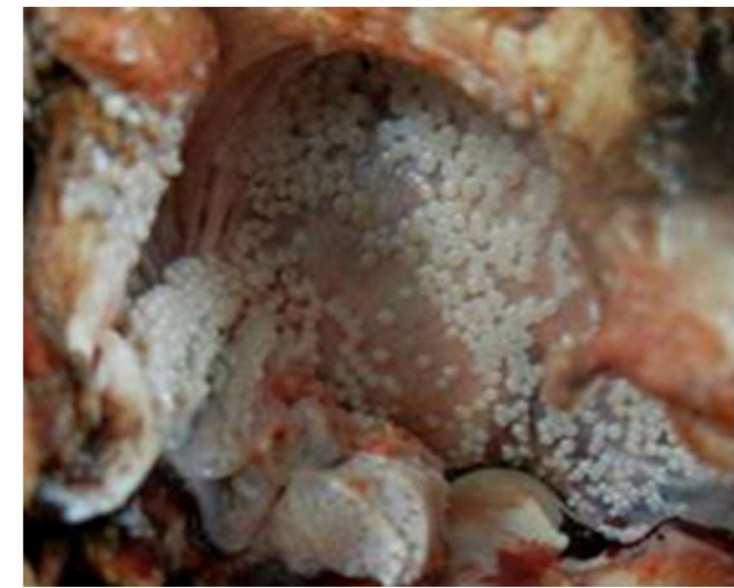

Figure 1 - Macroscopic view of the spermaceti chamber. Note the lining mucosa containing multiple whitish spherical vesicular structures (1-2 $\mathrm{mm}$ in diameter)

substance compatible with mucoproteic fluid were observed in HE stained slides. Vesicular walls formed by fibrous connective tissue containing abundant type
I collagen stained positive for Masson's trichrome. Structures similar to apocrine glands observed at the base of such vesicles are probably related to fluid production (Figure 2). Such glands and the fluid present within the vesicles stained positive for alcian blue and PAS staining, confirming that these glands have the same composition as the fluid within its vesicles. PAS staining demonstrated the presence of mucoid substances and/or polysaccharides, whereas alcian blue also stained polysaccharides, including some types of mucopolysaccharides. Alcian blue-PAS characterizes the fluid as composed of neutral polysaccharides. Thornton et al. (2015) previously described the histology of the vesicles lining the spermaceti chamber in K. breviceps, but to the author's knowledge, this is the first time glandular structures in the spermaceti chamber are identified and histologically characterized.

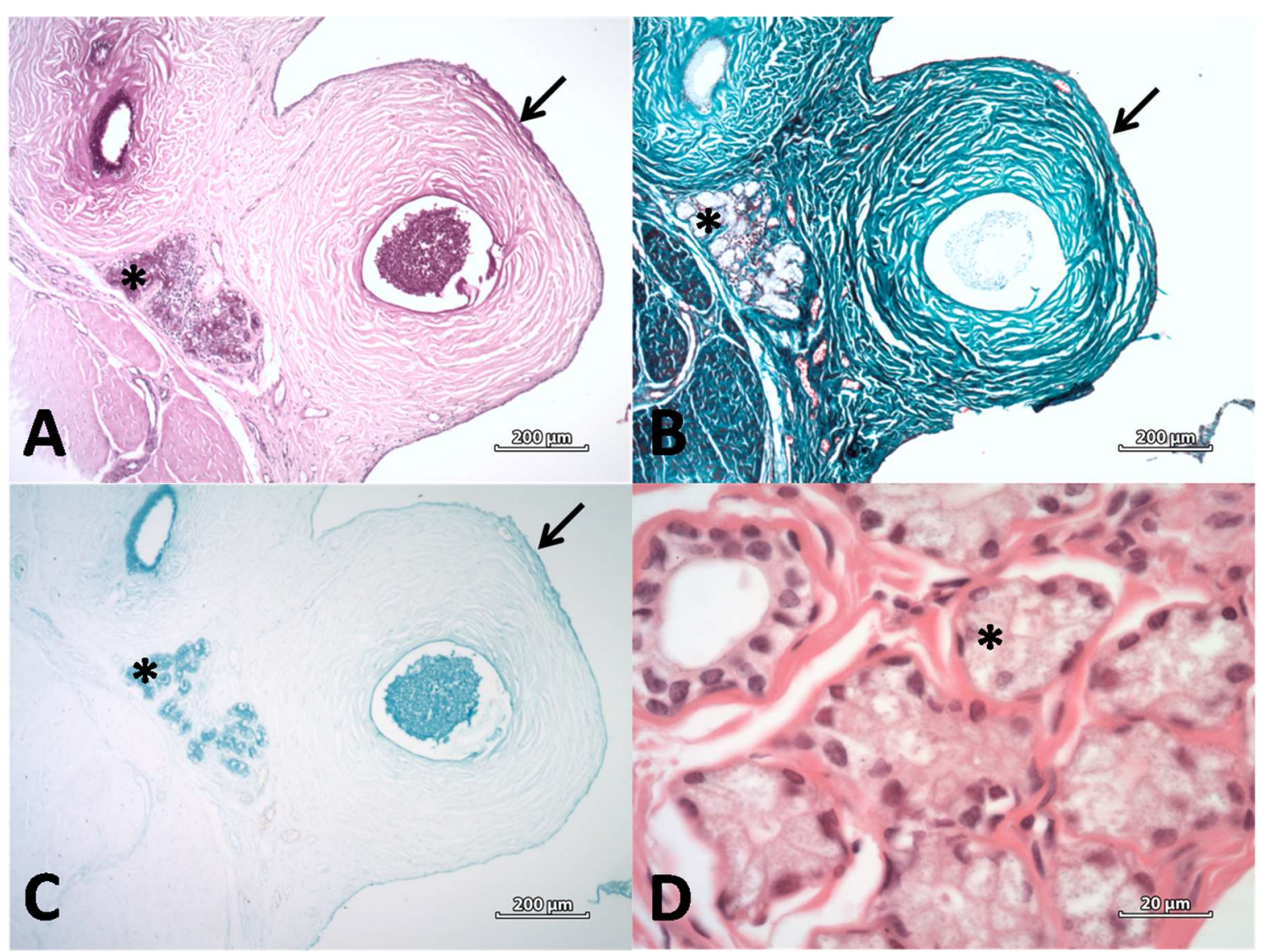

Figure 2 - Mucosa and submucosa of the spermaceti chamber, showing the vesicles (arrow) and apocrine glands (asterisk). Staining methods: A) PAS, B) Masson's trichrome, C) Alcian blue and D) Apocrine gland HE

It is believed that the spermaceti chamber of $K$. sima has the same function as the distal air sac of $P$. macrocephalus in the process of sound production. A similar mucosa, in contact with the phonic lips and the 
spermaceti, has been reported in P. macrocephalus (NORRIS; HARVEY, 1972); however, their vesicles are septated, and more irregular in shape than the ones observed in this in K. sima specimen (NORRIS; HARVEY, 1972). As described by Thornton et al. (2015) in Kogiidae, and Norris and Harvey (1972) in $P$. macrocephalus, the serous fluid present in the vesicles allows their deformation but not compression, possibly preventing the complete collapse of the spermaceti chamber while deep diving under high pressures. Such strategy maintains the air film within the spermaceti chamber, probably allowing this structure to act as a sound reflector (NORRIS; HARVEY, 1972), sending sounds to the phonics lips (KAROL et al., 1978; CLARKE, 2003) and the spermaceti organ (CLARKE, 2003).

\section{References}

CALDWELL, D.; PRESCOTT, J.; CALDWELL, M. Production of pulse sounds by the pygmy sperm whale, Kogia breviceps. Bulletin of the Southern California Academy of Sciences, v. 65, n. 4, p. 245-248, 1966.

CALDWELL, M. C.; CALDWELL, D. K. A note describing sounds recorded from two cetacean species, Kogia breviceps and Mesoplodon europaeus, stranded in northeastern Florida. In: MARINE MAMMAL STRANDINGS IN THE UNITED STATES: MARINE MAMMAL STRANDING WORKSHOP, 2., 1991, Miami. Proceedings... Miami: United States Department of Commerce, National Oceanic and Atmospheric Administration, Technical Report, National Marine Fisheries Service, 1991. p. 151-154.

CLARKE, M. R. Production and control of sound by the small sperm whales, Kogia breviceps and K. sima and their implications for other Cetacea. Journal of the Marine Biological Association of the United Kingdom, v. 83, n. 2, p. 241-263, 2003. doi: 10.1017/S0025315403007045h.

JONES, R. E. Food habits of smaller marine mammals from Northern California. Proceedings of the California Academy of Sciences, v. 42, n. 4, p. 409-433, 1981.

KAROL, R.; LITCHFIELD, C.; CALDWELL, D. K.; CALDWELL, M. C. Compositional topography of melon
The spermaceti chamber is lined by a mucosa containing vesicles formed by connective tissue walls, filled with mucoproteic fluid, probably produced by glands located deeper into the submucosa. These vesicles may act as a preventive system against the collapse of the spermaceti chamber.

\section{Acknowledgements}

The authors would like to thank Sândara Squario, Juliana Marigo and Jorge Oyakawa for their help with sample collection and processing, and the Aquário de Santos for allowing the use of its facilities. This study was funded by the Coordination for the Improvement of Higher Education Personnel (CAPES) and the São Paulo Research Foundation (FAPESP 2011/08357-0).

and spermaceti organ lipids in the pygmy sperm whale Kogia breviceps: implications for echolocation. Marine Biology, v. 47, n. 2, p. 115-123, 1978. doi: 10.1007/BF00395632.

NORRIS, K. S.; HARVEY, G. W. A theory for the function of the spermaceti organ of the sperm whale (Physeter catodon L.). In: GALLER, S. R.; SCHMIDT-KOENIG, K.; JACOBS, G. J.; BELLEVILLE, R. E. Animal Orientation and Navigation. Washington: NASA Scientific and Technical Office, 1972. p. 397-417.

REEVES, R. R.; STEWART, B. S.; CLAPHAM, P. J.; POWELL, J. A. In: KNOPF, A. A. National Audubon Society guide to Marine Mammals of the World. New York: Knopf Publishing Group, 2002. p. 244.

SCHENKKAN, E. J.; PURVES, P. E. The comparative anatomy of the nasal tract and the function of the spermaceti organ in the Physeteridae (Mammalia, Odontoceti). Bijdragen tot de Dierkunde, v. 43, n. 1, p. 93112, 1973.

SCOTT, M. D.; HOHN, A. A; WESTGATE, A. J.; NICOLAS, J. R.; WHITAKER, B. R.; CAMPBELL, W. B. A note on the release and tracking of a rehabilitated pygmy sperm whale (Kogia breviceps). Journal of Cetacean Research and Management, v. 3, n. 1, p. 87-94, 2001. 
SPITZ, J.; CHEREL, Y.; BERTIN, S.; KISZKA, J.; DEWEZ, A.; RIDOUX, V. Prey preferences among the community of deep-diving odontocetes from the Bay of Biscay, Northeast Atlantic. Deep Sea Research Part I: Oceanographic Research Papers, v. 58, n. 3, p. 273-282, 2011. doi: 10.1016/j.dsr.2010.12.009.

TAYLOR, B. L.; BAIRD, R.; BARLOW, J.; DAWSON, S. M.; FORD, J. K. B.; MEAD, J. G.; NOTARBARTOLO DI SCIARA, G.; WADE, P.; PITMAN, R. L. Kogia sima. IUCN Red List Threat Species, e.T11048A1, 2012a. doi: 10.2305/IUCN.UK.2012.RLTS.T11048A17695273.en.

TAYLOR, B. L.; BAIRD, R.; BARLOW, J.; DAWSON, S. M.; FORD, J. K. B.; MEAD, J. G.; NOTARBARTOLO DI SCIARA, G.; WADE, P.; PITMAN, R. L. Kogia breviceps. IUCN Red List Threat Species, e.T11047A1, 2012b. doi: 10.2305/IUCN.UK.2012.RLTS.T11047A17692192.en.
THORNTON, S. W.; MCLELLAN, W. A.; ROMMEL, S. A.; DILLAMAN, R. M.; NOWACEK, D. P.; KOOPMAN, H. N.; PABST, D. A. Morphology of the nasal apparatus in pygmy (Kogia Breviceps) and dwarf (K. Sima) sperm whales. The Anatomical Record, v. 298, n. 7, p. 1301-1326, 2015. doi: 10.1002/ar.23168.

WATWOOD, S. L.; MILLER, P. J. O.; JOHNSON, M.; MADSEN, P. T.; TYACK, P. L. Deep-diving foraging behaviour of sperm whales (Physeter macrocephalus). Journal of Animal Ecology, v. 75, n. 3, p. 814-825, 2006. doi: 10.1111/j.1365-2656.2006.01101.x.

WOOD, F. G. General discussion. In: TAVOLGA, W. Marine Bio-Acoustics. New York: Pergamon Press, 1964. p. 395-398. 